Article

\title{
The Evolutionary Trajectory of the Agile Concept Viewed from a Management Fashion Perspective
}

\author{
Dag Øivind Madsen $\mathbb{D}$ \\ Department of Business, Marketing and Law, School of Business, University of South-Eastern Norway, \\ Bredalsveien 14, 3511 Hønefoss, Norway; dag.oivind.madsen@usn.no
}

Received: 11 March 2020; Accepted: 22 April 2020; Published: 6 May 2020

\begin{abstract}
Agile is one of the most popular contemporary management concepts and buzzwords. This paper provides an in-depth examination of the influence of the Agile concept on the discourse, thinking and practices of organizations worldwide. The paper traces the emergence and evolution of the Agile concept from inception to the present by synthesizing findings from a wide range of academic and practitioner-oriented sources. Overall, the picture that emerges from the analysis is that the Agile concept has grown considerably in popularity and has become one of the most dominant concepts in public management discourse. The popularization of Agile has, to a large extent, been driven by an active supply-side made up of actors such as consultants, coaches, and trainers. Another finding is that the Agile concept has evolved considerably over time, from its initial presentation as a narrow and specialized concept rooted in the software development community to a much broader and general approach applicable across nearly all types of organizations and industries. The broadening of the concept has led to neologisms such as Agile Marketing, Agile Government, and Agile Management. The paper ends with reflections on the current status of Agile and some speculation about the concept's likely future trajectory.
\end{abstract}

Keywords: Agile; management concept; management fashion; emergence; evolution

\section{Introduction}

A standard definition of Agile is that it is "... the ability to create and respond to change. It is a way of dealing with, and ultimately succeeding in, an uncertain and turbulent environment" (Agile Alliance 2020). Gren and Lenberg (2019) have proposed a shorter and more straightforward definition of Agile as "responsiveness to change". From these definitions, it becomes clear that the concept of Agile is mostly concerned with organizational responsiveness and adaptability in what many commentators describe as increasingly turbulent and dynamic competitive environments (Bennett and Lemoine 2014a; Kaarbøe et al. 2013; Millar et al. 2018).

The concept of Agile was popularized in the "Agile Manifesto" in 2001 (Beck et al. 2001). In the early 2000s, it was a relatively narrow and specialized concept that was focused on the software development community. Today, Agile has become a much more mainstream management concept, which is sometimes referred to under the generic label of Agile Management. It is safe to say that Agile is currently one of the most popular catchwords in the management community (Nyce 2017; The Economist 2018). In the business press and management literature, it is often claimed that organizations operate in an "age of Agile" (Denning 2017a) and in an "Agile world" (Denning 20181).

The Agile concept has a broad appeal and is impacting a wide range of discourses, evidenced by talk not only of "Agile Software Development" but increasingly of applications of Agile thinking in other areas; e.g., "Agile Innovation (Rigby et al. 2015), "Agile Marketing" (Accardi-Petersen 2012; Poolton et al. 2006) and "Agile HR" (Bhatta and Thite 2019; Scully 2013). There are also numerous linguistic variants that reflect Agile thinking, such as "agility" (Prange and Heracleous 2018a), 
“leadership agility" (Horney et al. 2010), "agile leaders" (Hosking 2018), and "agile business leaders" (Millar et al. 2018).

The impact of Agile is, however, not only confined to the discursive level. Recently, it has been noted that the concept of Agile has become fashionable (Nyce 2017; The Economist 2018) and is spreading rapidly to "every part and every kind of organization" (Denning 20181). Various surveys carried out in recent years also demonstrate the increasing impact of Agile on organizations worldwide. For example, Bain \& Company's "Management Tools and Trends" survey provides a clear indication that Agile is gaining ground in management practice. In 2018, Agile Management debuted in the top 25 with an adoption rate of $24 \%$ (Rigby and Bilodeau 2018), which suggests that Agile has quickly become a very timely and popular concept among managers around the world. Agile Management is one of the newest and fastest-climbing concepts in the top 25 list, matched only by Big Data Analytics.

\subsection{Purpose}

There is much speculation and debate about the future viability and trajectory of the Agile concept. In recent years, several commentators have debated the question of whether Agile is the latest in a long line of managerial fads (Denning 2015d, 2018i; Kupersmith 2011). Some hold the view that Agile has run its course and have, for example, proclaimed that "Agile is dead" (Kern 2016). Others are more pessimistic and see dark skies on the horizon; for example, it has been argued that that the Agile concept is in crisis (Wischweh 2019) and that we may be approaching the "end of Agile" (Cagle 2019a, 2019b; Kruchten 2019).

On the other side, some remain optimistic about the viability and future trajectory of Agile and argue that it is reflective of a more lasting organizational trend. Several reports published in recent years support this view. These reports show that Agile has grown considerably in popularity in recent years and become highly fashionable (Denning 2017a; Rigby and Bilodeau 2018; The Economist 2018).

In light of these conflicting views of the current status and the future trajectory of the concept, it is becoming important to take a historical view of the emergence and evolution of the concept in order to obtain a better understanding of how the Agile concept has impacted the discourse, thinking and practice in the organizational community. In this paper, the management fashion perspective (Abrahamson 1996; Abrahamson and Piazza 2019; Benders and Van Veen 2001; Kieser 1997; Piazza and Abrahamson 2020) will be used as a theoretical lens to analyze the emergence and evolution of Agile. The lens of management fashion is well-suited for this purpose since this theory focuses on the macro-level lifecycle and trajectory of management concepts and ideas (Madsen and Slåtten 2015a; Perkmann and Spicer 2008).

While management fashion theory has not been extensively used in the context of Agile, this paper is not the first to argue for the applicability of the management fashion perspective to shed light on the evolution of the Agile concept. In a recent contribution, Cram and Newell (2016) used management fashion theory to examine Agile Development and the way that five adopting organizations have responded to this trendy management concept. However, the current paper takes a different approach in that the focus is not on the micro-level adaptations and translations of the concept made by demand-side organizations but rather the concept's macro-level evolutionary trajectory.

Studying the Agile concept's historical evolutionary trajectory provides new, deeper insight into how the concept has originated, emerged, and evolved over time, as well as the various contextual factors that have shaped its trajectory. Schwarz $(2015$, p. 499) has noted the importance of studying the historical evolution of management concepts since "[w]e can increase our knowledge of these important management concepts by understanding their historical roots and how the ideas surrounding the concepts have evolved over time".

More broadly, the current study contributes to the literature on Agile as a management concept by providing an in-depth case study of the concept's emergence and evolution, synthesizing evidence from a wide spectrum of sources. Agile's evolutionary trajectory has not been particularly well-documented compared to other management concepts (e.g., Total Quality Management, Lean Management, and 
Business Process Reengineering) which have been studied quite extensively (see e.g., Benders et al. 2019; David and Strang 2006; Jung and Lee 2016; Wilkinson and Willmott 1995).

\subsection{Structure}

The paper is structured in the following way. Section 2 provides a brief overview of the research approach. Section 3 provides a brief history of the Agile concept. Section 4 analyzes the framing and characteristics of the concept. In Sections 5 and 6, the supply and demand sides of Agile are described and analyzed. In Section 7, a theoretical discussion of several aspects of the emergence and evolution of the concept is presented. Lastly, Section 8 concludes and discusses the paper's limitations as well as areas for future work.

\section{Research Approach}

The current paper aims to provide a historical overview of the emergence and evolution of the Agile concept from its introduction to the present time. In other words, the paper examines in greater detail the extent to which the Agile concept has influenced the discourse, thinking, and practices of organizations worldwide.

To accomplish this, a macro-level, historical approach is followed, in which literature from a wide variety of sources (both scholarly and practitioner-oriented) are synthesized to construct a "mosaic" (Morrison and Wensley 1991) and historical narrative of the concept's evolutionary trajectory.

In this paper, the literature search followed a method most accurately characterized as a snowball-type procedure. Google Scholar was used to identify key books and articles which have examined the Agile concept as a fad, fashion or trend (e.g., Cram and Newell 2016; Denning 2015d; Prange and Heracleous 2018a). These papers were then used to identify other related papers. The procedure involved a mix of backward snowballing (examining the bibliographies of the key papers) and forward snowballing (examining newer papers citing the key papers) (see, e.g., Felizardo et al. 2016; Jalali and Wohlin 2012; Wohlin 2014).

Overall, the desk-research approach employed in this paper is a pragmatic choice given the aims and constraints of the study. At the same time, this approach has several limitations, which will be discussed in greater depth in the final section of the paper.

\section{A Brief History of Agile}

This section provides a brief history of the Agile concept. This overview is deemed important because it provides an overview of various contextual factors that have shaped the emergence and evolution of Agile. The section starts by providing a brief description of the concept's origins and roots, followed by a discussion of how the concept has evolved over time from a specialized niche concept to a broader management approach that can be applied to almost any aspect of businesses and organizations.

\subsection{Origins and Emergence}

It is not very easy to pinpoint the exact origins and birthplace of Agile. Several researchers have written about the roots of Agile thinking (Abbas et al. 2008; Prange and Heracleous 2018b; Rigby et al. 2016b; Whiteley et al. 2019) and have shown that the thinking behind the concept can be traced back several decades. For example, Prange and Heracleous (2018b, p. 2) argue that Agile thinking has roots in several academic fields such as sociology, education and manufacturing. Others point out the concept's roots in the software programming community during the 1990s (Meyer 2014).

While there are differing opinions about the roots of Agile thinking, it has been well-documented that the concept of Agile was popularized around the turn of the millennium, largely as a result of the publication of the "The Agile Manifesto" (www.agilemanifesto.org) (Beck et al. 2001). The 17 authors of the Manifesto were influential thinkers from the software community. The Manifesto contained a broad-based description of the Agile concept and outlined four foundational values and 12 principles of 
Agile Software Development. In other contributions, it has been noted that the launch of the Manifesto started the "Agile movement" (Nyce 2017; Rigby et al. 2016b).

\subsection{Evolution}

The Agile concept has been dynamic and has evolved considerably over time. The evolutionary trajectory of Agile has, over the course of the last two decades, been shaped by (1) changes in the business environment, and (2) a shift in the zeitgeist in the business world.

The term "VUCA World" (Bennett and Lemoine 2014a, 2014b) refers to this new turbulent and dynamic business environment (VUCA = volatility, uncertainty, complexity and ambiguity). In a similar vein, other writers such as Taleb (2007) point out the importance and impact of highly improbable events and the difficulties of managing organizations in such an environment. The notion of a "VUCA world" and the difficulties in predicting the future underscore the need for "strategic agility" (Doz and Kosonen 2008; Doz and Kosonen 2010; Kotter 2014; Lewis et al. 2014), which refers to the ability to quickly change and adapt strategies and business models to changing market conditions and competitors.

Several important developments have taken place during the 2000s and 2010s, which have made the zeitgeist favorable to the Agile movement. During this time, the thinking and focus in the strategic management community shifted towards a stronger emphasis on disruptive innovations and business model innovation (Christensen 2006; Johnson 2010; Kim and Mauborgne 2005, 2017). For example, during the 2010s, there was a much sharper focus on the increasingly dynamic nature of the business environment (Kaarbøe et al. 2013).

Therefore, it can be argued that the Agile concept fits well with the new zeitgeist, which has been dominant in the business community since the early 2000s. As Kieser (1997) has pointed out, timing plays an essential role in deciding whether a novel management concept appeals to managers in the business community (Kieser 1997). In the words of Kieser (1997), the new management concept must hit the "nerve of today's managers" (Kieser 1997, p. 61). Therefore, new concepts and ideas have to be timely and address salient issues that managers are currently interested in and which they perceive as important.

\section{The Framing and Characteristics of Agile}

This section describes and analyzes the framing and characteristics of the Agile concept. The section starts with a brief discussion of whether Agile fits the definition of a management concept, followed by an examination of the key characteristics of management concepts that have the potential to become fashionable. This analysis unpacks different aspects of the framing and packaging of the Agile concept.

\subsection{Agile as a Management Concept}

Before proceeding, it is useful to consider the definition of a management concept. One standard definition is that management concepts are "prescriptive, more or less coherent views on management" (Braam et al. 2007, p. 868). There is a long list of management concepts and ideas that have been introduced during the last 100 years or so (Bort 2015; Hindle 2008; Rigby and Bilodeau 2018; Sibbet 1997; Sturdy et al. 2019). Some well-known contemporary examples include Lean Management, Customer Relationship Management, Balanced Scorecard, and Beyond Budgeting. While the influence and impact of particular management concepts vary across time and space, there is little doubt that management concepts continue to "play an important role in shaping contemporary organizational processes, structures and organizational behavior" (Braam et al. 2007, p. 868).

As noted earlier, Agile can be considered a relatively young management concept and part of the small millennial generation of management concepts. Agile fits the above definition of a management concept outlined by Braam et al. (2007) since it is highly normative and provides prescriptions to managers about organizational structures and processes. For example, the Agile concept contains several broad foundational values and a list of principles for users to follow. 
While Agile can be considered a management concept, this does not automatically mean that it will become a popular (i.e., fashionable) management concept. In the literature on management concepts and ideas, it is noted that not all concepts are framed in the right way; i.e., in a way that is appealing and attractive to managers. Researchers studying management fashions (Benders and Van Veen 2001; Huczynski 1992; Røvik 2002), have identified several key characteristics of concepts, which usually are part of the "winning formula". In the following, the focus will be on four characteristics of the Agile concept: (1) label, (2) performance improvements, (3) interpretive space and (4) universality.

\subsection{Label}

The way a management concept is labeled plays an essential role in determining whether it will become popular (Kieser 1997; Røvik 1998). It is helpful if the label is catchy and has buzzword qualities (Cluley 2013; Collins 2000). Grint (1997) points out that popular concepts are often known by three-letter acronyms (e.g., TQM [Total Quality Management], BPR [Business Process Reengineering]). Agile is not associated with an acronym, but this can be explained by the fact that the label is arguably short and catchy enough that an abbreviation is not needed. Furthermore, similar to many other management concepts (e.g., Balanced Scorecard, Lean Management), the concept of Agile conjures positive connotations since it is filled with terminology commonly associated with sports and fitness (cf. Kieser 2002). The word "agile" also easily triggers images of fit athletes (e.g., flexible gymnasts) and calls to mind images of innovation and adaptability. This makes the concept appealing to managers who want their organizations to be adaptable and speedy. In this new turbulent business environment (Kaarbøe et al. 2013), it is becoming difficult for managers to be against being "agile" and having the ability to adapt quickly. The introduction of terms such as "agile leaders" (Hosking 2018) and "agile business leaders" (Millar et al. 2018) also plays directly to the identity of managers and how they want to think of themselves. In this way, the Agile concept can viewed as what Briers and Chua (2001, p. 242) label a visionary object: "These are conceptual objects that have high levels of legitimacy within a particular community. They can evoke similar emotive and affective responses from a wide spectrum of people, possessing a sacred quality that makes it difficult for a 'rational' person to be against them".

Another aspect of the way the Agile concept is labeled is that it easily lends itself to the development of neologisms. In previous research, it has been noted that Agile is typically combined with different nouns ("Agile" plus "Manufacturing/Marketing/Innovation") (Kruchten 2019). In the literature, it is possible to identify a wide range of neologisms related to marketing, HR, innovation and government, to name just a few examples (Table 1).

Table 1. Examples of Agile neologisms.

\begin{tabular}{cc}
\hline Neologism & Reference \\
\hline Agile Manufacturing & $\begin{array}{c}\text { Gunasekaran (1998, 2001), Hussain and Gunasekaran (2002), } \\
\text { Yusuf et al. (1999) }\end{array}$ \\
\hline Agile Project Management & Hass (2007), Layton and Ostermiller (2017) \\
\hline Agile Supply Chain & Christopher (2000), Christopher et al. (2004) \\
\hline Agile Procurement & Nicoletti (2018) \\
\hline Agile Management Accounting & Taipaleenmäki (2017) \\
\hline Agile Portfolio Management & Laanti et al. (2015) \\
\hline Agile Financial Planning & Sirkiä and Laanti (2013) \\
\hline Agile Finance \& Control & Stormi et al. (2019) \\
\hline Agile Performance Measurement System & Bhatta and Thite (2019), Scully (2013) \\
\hline Agile HR & Denning (2018k) \\
\hline Agile People Management & Alexandre et al. (2020) \\
\hline Agile Governance & Twidale and Hansen (2019) \\
\hline Agile Research &
\end{tabular}


Table 1. Cont

\begin{tabular}{cc}
\hline Neologism & Reference \\
\hline Agile Marketing & Accardi-Petersen (2012), Poolton et al. (2006) \\
\hline Agile Innovation & Rigby et al. (2015) \\
\hline Agile Innovation Management in Government & Mergel (2016) \\
\hline Agile Government & (2018) \\
\hline Agile Local Governments & Soe and Drechsler (2018) \\
\hline
\end{tabular}

\subsection{Performance Improvements}

A second characteristic of the way management concepts are framed is the heavy use of strong promises of performance improvements post-implementation (Kieser 1997; Røvik 1998; ten Bos 2000). Proponents of new concepts often use optimistic and enthusiastic rhetoric to attract the interest of managers and entice them to adopt the concept. As pointed out by Benders (1999), highlighting the potential positive effects of a novel concept is necessary for it to diffuse quickly and widely since managers are unlikely to adopt a concept unless they perceive substantial benefits.

In the literature on Agile, there are lofty claims that the use of Agile will greatly increase organizational performance. One example is Ulrich and Yeung (2019), who argue that Agile is "the capability du jour" (Denning 2019a, 2019b). It is also often implied that non-adopters (non-agile organizations) will be slow and unresponsive to changes, as well as "fragile", which plays to managers' psychological fears of missing the boat and being at a competitive disadvantage vis-à-vis their competitors (Kieser 1997; Sturdy 2004).

\subsection{Interpretive Space}

A third characteristic of the framing of management concepts is that they are quite abstract and vague (Benders and Van Veen 2001; Örtenblad 2010). In the management fashion literature, this characteristic is commonly referred to as "interpretive space" or "interpretive viability" (Benders and Van Veen 2001; Clark 2004), which means that a concept may be understood and interpreted differently by different actors.

Several researchers have noted the interpretive space of the Agile concept. Table 2 shows illustrative quotes on the interpretative space of Agile. In the words of Moore (2017, p. 4), there is "a recognition among both practitioners and theorists that in its usage the term Agile is actually vague and subject to somewhat plural understandings". Agile is an elusive concept that can be hard to define. Prange and Heracleous (2018b, p. 3) note that there is "no precise or commonly accepted understanding of the term". Yip (2016, para. 1) notes that "[t]he word "Agile" can trick us into believing that we are talking about the same thing when we are actually not".

Table 2. The interpretive space of the Agile concept.

\begin{tabular}{cc}
\hline Illustrative Quote & References \\
\hline "amorphous nature" & George et al. (2018) \\
\hline "multiple, loose connotations" & Moore (2017) \\
\hline "multiple meanings" & Denning (2018j)
\end{tabular}

Due to the ambiguity and fluidity of the concept, managers have to interpret and make sense of Agile (Denning 2018h). The well-known business researcher Bob Sutton has made the following observation on Twitter about Agile": "I talked to 50+ leaders and consultants about what "Agile"

1 https://twitter.com/work_matters/status/1040309613113954304?lang=en. 
means. Read 10+ books. I agree with many principles and grasped it when it focused on software. I am now confused. It has become a huge tent with varied jargon monoxide".

The conceptual confusion and lack of consensus on what the concept should be concerned with necessarily leads to varying interpretations and translations of Agile (Weiderstål and Johansson 2018). For example, Yip (2016) points out that the concept can be interpreted in many different ways: e.g., as "a synonym for good", "a particular workflow", "a set of practices", "an ideal", "a set of target outcomes", "the community", or "a doctrine".

Moreover, the interpretive space of the Agile concept can also help explain the wide range of neologisms identified in Table 1 in Section 4.2. The room for interpretation means that Agile can relatively easily be adapted and combined with almost any other management concept, approach or buzzword. In the literature, there is considerable evidence of different mashups of the Agile concept, such as "Leagile" (Mason-Jones et al. 2000).

\subsection{Universality}

The final characteristic is related to the fact that management concepts are presented as universally applicable (Kieser 1997; Røvik 1998). The supporters of novel concepts typically argue that they are useful and applicable in almost any organization, irrespective of the organizational or societal context (Wittrock 2015). Although Agile was initially concerned with software development, over time, the concept has become a much broader management approach. Proponents now argue that the Agile concept can be applied anywhere (Hazzan and Dubinsky 2014). Therefore, it can be argued that the universality of Agile has increased over time as the concept has evolved from its initial presentation as Agile Software Development to its present-day presentation as a broader management concept (Agile Management). The concept has also widened its appeal considerably over time and can today be found in a wide range of discourses and organizational communities.

\section{The Supply-Side of Agile}

This section examines and analyzes the supply-side of Agile; i.e., the actors involved in the development, propagation, and promotion of the Agile concept. The actors on the supply-side of the management fashion market (e.g., consulting firms, management gurus, business school professors) are often referred to as "the fashion-setting community" (Abrahamson 1996) or the "management fashion arena" (Jung and Kieser 2012). These actors generally have vested interests in furthering and preserving the popularity of the management concept, and therefore not only compete but also cooperate to increase the total market size related to the concept in question (Kieser 1997; Klincewicz 2006). In the case of Agile, there are many indications that supply-side actors have behaved in ways similar to this. For example, commentators have noted the role of the "Agile Industrial Complex" in turning the Agile concept into a big business (Mezick 2016; Wischweh 2019).

In the following, the discussion will focus on six types of actors who are deemed to have been particularly important in the case of Agile: (1) consulting firms, (2) management gurus, (3) conference and seminar organizers, (4) trainers and coaches, (5) business schools, and (6) business and social media.

\subsection{Consulting Firms}

Consulting firms are often viewed as the most central actor in the management fashion arena (Jung and Kieser 2012; Kieser 1997). These advisory firms are heavily involved in the production, dissemination and hyping of new management concepts (David and Strang 2006; Heusinkveld 2013; Jung and Kieser 2012). They are also often involved in the application and roll-out of new management concepts in client organizations (Heusinkveld and Benders 2012).

Influential players in the management consulting industry, such as McKinsey and Deloitte, have published many articles about Agile. For example, McKinsey consultants have written quite extensively about Agile in their influential publication McKinsey Quarterly (Aghina et al. 2015; Bazigos et al. 2015; Heiligtag et al. 2015; Macias-Lizaso and Thiel 2006; Sull 2010). Recently, McKinsey Digital has published 
articles about how to create an Agile organization (Ahlbäck et al. 2017) as well as Agile coaching (Anand et al. 2019). Deloitte has also carried out global surveys showing that Agile practices are increasingly viewed as playing an important role in the "organization of the future" (Deloitte 2017).

\subsection{Management Gurus}

Management gurus play essential roles in legitimizing new management concepts by doing much of the initial trailblazing, such as presenting these ideas in public forums (Collins 2019; Huczynski 1993). The concept of Agile is not associated with a single management guru; instead, the numerous co-signers of the Agile Manifesto may all be considered Agile gurus. However, in the years following the publication of the Manifesto, they have taken the original Agile thinking in different directions.

Moreover, other thinkers and thought leaders have also thrown their hats into the ring and established high profiles in relation to Agile. For example, Stephen Denning is a prolific writer on business issues who has become a vocal commenter on Agile. Denning has published a string of articles in magazines such as Forbes (Denning 2012, 2015a, 2015c, 2015d, 2016a, 2016c, 2018c, 2018d, 2018e, 2018i, 2018j, 2019a, 2019e, 2019f, 2019g, 2019i) and the practitioner-oriented journal Strategy \& Leadership (Denning 2015b, 2015e, 2016b, 2017a, 2017b, 2018f, 2018g, 2018h, 2018k, 20181, 2019c, 2019d). He has also published a book on Agile (Denning 2018b).

Some management gurus associated with other management concepts have also adopted and embraced some aspects of Agile thinking. One example is Bjarte Bogsnes, a leading figure in the Beyond Budgeting movement, who has written and spoken about Agile in the context of Beyond Budgeting (Bogsnes 2016).

\subsection{Conference and Seminar Organizers}

Conference and seminars can be considered important meeting places where new management and ideas are presented and discussed (Kieser 1997; Røvik 1998). At these events, suppliers and consumers of concepts meet and interact (Madsen 2014). Therefore, such events may function as "breeding grounds" for new concepts and ideas (Røvik 1998). In the case of Agile, there is much evidence of activity on the conference and seminar circuit. There are numerous Agile-related conferences, such as the International Conference on Agile Software Development and the North American Agile Conference (Hoda et al. 2018). In recent years, another example has been the World Agility Forum (www.worldagilityforum.com) (Denning 2019a, 2019i). At this event, awards are given out for different types of agility (e.g., Lifetime Agility, Leadership Agility, Team Agility, Design and Creativity Agility).

\subsection{Trainers and Coaches}

There is a large market for Agile training, coaching, and various types of certifications (Mezick 2016; Wischweh 2019). Consulting firms are also involved in this market. For example, one of the aforementioned McKinsey articles describes how organizations can develop in-house Agile coaches (Anand et al. 2019).

Training and coaching are effective ways to entrench and institutionalize management concepts. A reason for this is that trainees and new holders of certifications develop a vested interest in the preservation of the approach. After all, concept-specific certifications lose much of their value if the concept becomes unfashionable. Often, participants obtain certifications after having attended training and having been coached on how to apply the concept in practice.

Training and coaching may also socialize new adopters and users of a concept and turn them into firm "believers." In research into other concepts such as Quality Management and Lean (Sørhaug 2016; Tuckman 1994), it has been suggested that training seminars could have a powerful impact on attendees. After having been exposed to these new concepts and ideas, some of them report having "seen the light" and are converted to a new way of thinking about business and organizational issues. In the context of Agile, several commentators have observed that the Agile movement has religious and cult-like aspects (Agile Anon 2016; Byker 2017). 


\subsection{Business Schools}

Business schools incorporate new management concepts and ideas in course curricula, textbooks and case studies used in management education programs (Engwall and Wedlin 2019; Sahlin-Andersson and Engwall 2002). In this way, business schools contribute to the legitimization and institutionalization of new management concepts.

In the case of Agile, business schools have played a relatively passive role, particularly during the concept's early days. As noted in Section 3, Agile was not developed in a business school environment. Instead, it is a predominantly practice-driven concept that was initially proposed by the software development community.

However, over time, the concept has also become the focus of business school researchers and teachers. For example, the concept has become quite widely used in business school education, evidenced by the number of case studies discussing Agile-related issues. A search for the term "Agile" on the website The Case Centre (www.thecasecentre.org) results in 438 product hits, including many case studies meant for classroom use at the MBA and executive education level.

Over time, business school academics have also taken up Agile as a topic for peer-reviewed research. While much of the early research on Agile has been carried out by researchers from the software engineering community (Dingsøyr et al. 2012; Dybå and Dingsøyr 2008), in the later phase, researchers from a wide range of fields have studied Agile using different types of theories and methods. Since the early 2000s, Agile research has grown almost exponentially, and much of this research has been published in highly ranked journals on software engineering and development (Hoda et al. 2018). Since the concept has become a broader and more general management concept, it has also started attracting the attention of business and management scholars.

To illustrate the development of Agile-related research, a search of the Scopus database was conducted. Figure 1 shows the evolution of research on three types of Agile (Agile Software Development, Agile Project Management, and Agile Manufacturing). The curves reveal a steady increase in the number of Scopus-indexed publications.

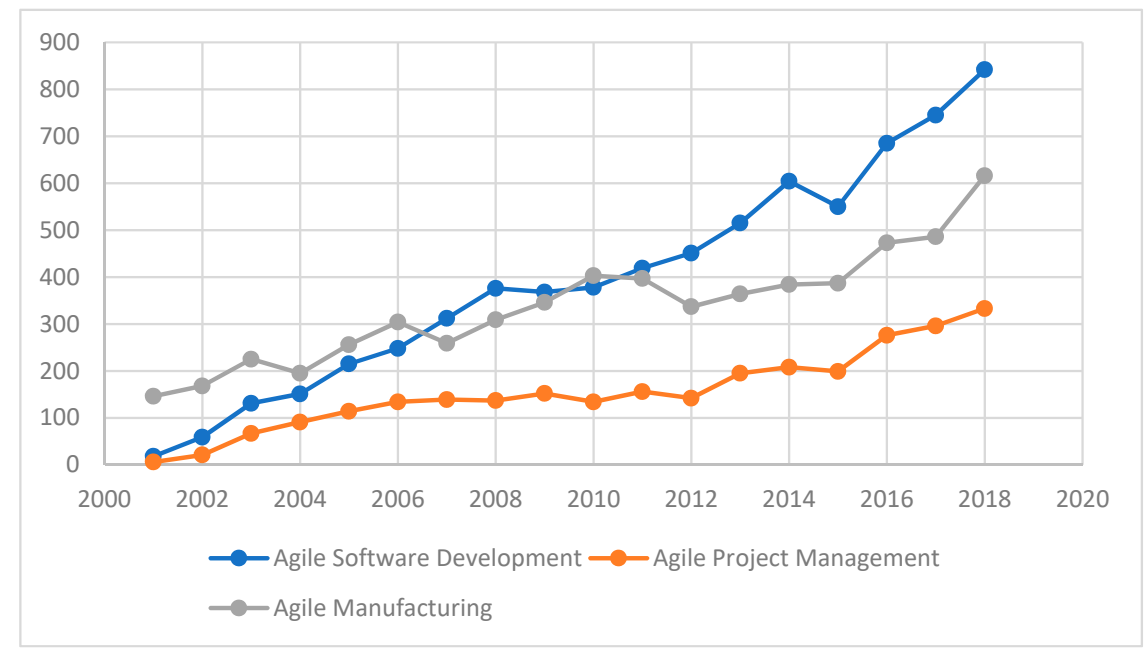

Figure 1. Hits in the Scopus database for selected Agile types (article title, abstract, keywords) in the period 2000-2018.

\subsection{Business and Social Media}

Business media (e.g., book publishers, business magazines, and newspapers) play an important role in the diffusion and dissemination of management concepts and ideas (Barros and Rüling 2019). In recent years, much of the discourse around new management concepts and ideas has taken place via the Internet and social media platforms such as LinkedIn and Twitter (Madsen and Slåtten 2015b). 
Since the concept's inception in the early 2000s, a large number of books have been published about different aspects of Agile (Augustine 2005; Dierdorf 2019; Hass 2007; Medinilla 2012a; Meyer 2016). In these books, the authors typically put their own spin on the concept and tailor it to a specific area of application. Another indication of the Agile concept's popularity is the release of several "Dummies" books, such as "Agile for Dummies" (Ambler and Holitza 2012) and "Agile Project Management for Dummies" (Layton and Ostermiller 2017).

Both traditional print-media outlets and social media have contained discussions about the Agile concept and the notion of agility. Several influential business publications have written about the Agile concept. One example is the Harvard Business Review article "Embracing Agile" (Rigby et al. 2016a). The business magazine Forbes has also been influential and has published numerous articles on Agile (Blomstrom 2019a, 2019b, 2019c, 2019d, 2019e, 2019f; Cagle 2019a, 2019b, 2019c; Davies 2019; Denning 2018a; Denning 2015c, 2015d, 2016a, 2016c, 2018c, 2018d, 2018e, 2018i, 2018j, 2019e, 2019f, 2019g, 2019i; Forbes Insights 2018). There are also Wall Street Journal articles (Castellanos 2019; Shellenbarger 2019), and the practitioner-oriented journal Strategy \& Leadership has published many articles on Agile (Denning 2015b, 2015e, 2016b, 2017a, 2017b, 2018f, 2018g, 2018h, 2018k, 20181, 2019c, 2019d, 2019h). Lately, there has also been considerable discourse about Agile on various social media platforms and web blogs (e.g., Agile Anon 2016; Byker 2017; Wischweh 2019).

\section{The Demand-Side of Agile}

\subsection{Interest}

Google Trends is an analytical tool that gives an indication of the evolution in the popularity of different search terms (Choi and Varian 2012). In previous research, it has been suggested that Google Trends can be used to gauge the interest in and salience of management concepts and ideas (Madsen 2016b). Figure 2 shows the evolution of interest in three types of Agile (Agile Software Development, Agile Management, and Agile Coaching). Figure 2 clearly shows that Agile Software Development is more popular than the other types of Agile, for which the Google Trends curves are, in comparison, nearly flat. This finding could be interpreted as an indication that the other types of Agile have mostly had an impact at the discursive level and have not induced much search activity by actors on the demand-side.

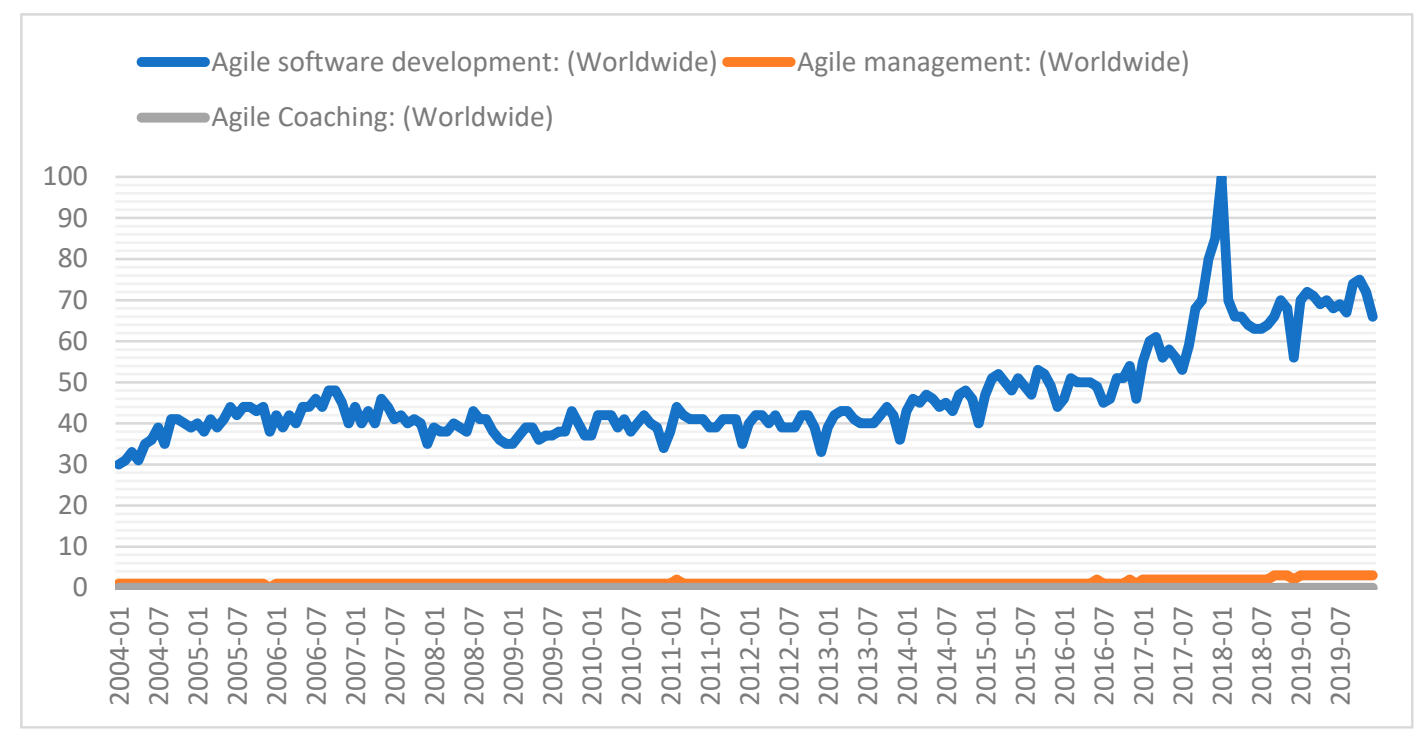

Figure 2. Google Trends for three types of Agile (data source: www.trends.google.com, retrieved 5 December 2019). 
However, when looking at Agile Management separately, it appears that the search interest is on the rise (Figure 3). This finding is more in line with the increasing number of articles on the topic in high-profile business magazines.

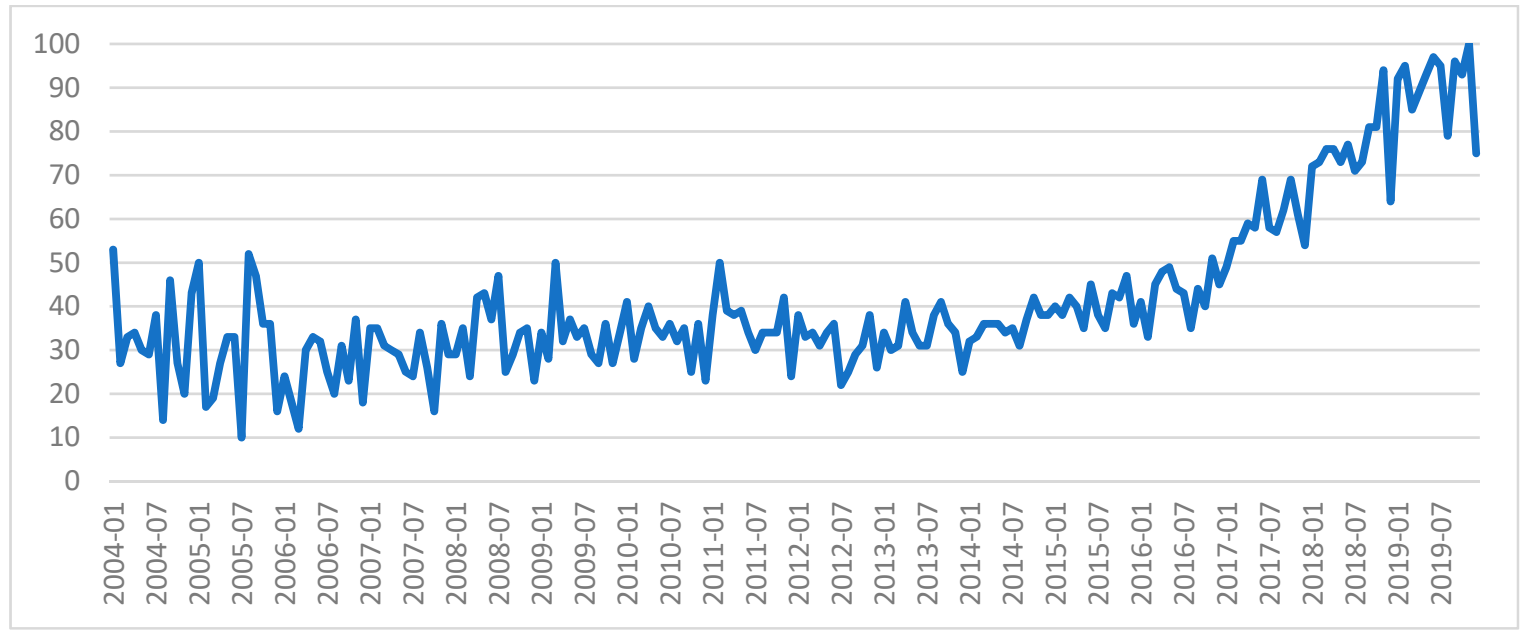

Figure 3. Google Trends for the search term "Agile Management" (worldwide) (data source: www. trends.google.com, retrieved 5 December 2019).

\subsection{Adoption and Diffusion}

Due to the Agile concept's nature and the multitude of variations of Agile, it is not easy to assess the adoption and diffusion of the concept. The label and the actual practices associated with it have become loosely coupled (Benders and Bijsterveld 2000; Benders and Van Veen 2001). Skeels (2018) notes that most things can be labeled as Agile. It is clear that Agile thinking has become widely adopted. Commentators have noted that Agile is currently prevalent and fashionable (The Economist 2018), and that the concept has spread to nearly "every part and every kind of organization" (Denning 20181). Studies suggest that Agile is no longer a private-sector phenomenon but has spread to different types of government organizations as well (Mergel 2016; Mergel et al. 2018; Soe and Drechsler 2018).

Several other recent surveys also paint a relatively optimistic picture of the adoption and diffusion of Agile. The Annual State of Agile surveys (www.stateofagile.com) show a growth in the adoption and use of Agile (Collabnet Versionone 2018; Versionone 2017). For example, in 2018, 97\% of respondents reported that their organization uses some types of Agile practices (Collabnet Versionone 2018). Similarly, Bain \& Company's "Management Tools and Trends" survey provides some support for the view that Agile is rising in popularity and use in practice. In 2017, Agile Management debuted in the top 25 of Bain \& Company's "Management Tools and Trends" survey with an adoption rate of 24\% (Rigby and Bilodeau 2018). This recent development suggests an uptick in the popularity of Agile. Furthermore, Rigby and Bilodeau (2018) have a relatively positive view of the future popularity of the concept. They note that Agile is "[a] new concept still for many managers, it is not yet widely used, but its high satisfaction rankings among those who do use it point to growth moving forward".

\subsection{Implementation}

As shown in Section 4, the Agile concept is rather vague, elusive, and hard to define. As a result, there are many different interpretations of Agile and this may lead to variations in how Agile is implemented across organizations. The interpretive space of the concept means that users of Agile tend to pick and choose elements to fit their needs and circumstances (George et al. 2018). Skeels (2018) made the following observation concerning the implementation of Agile: "[T]heir Agile is all about dozens of random organizational changes that are labeled "Agile," and are cited as proof of Agile's greatness. Someone says they are doing or being Agile? Ipso facto, they must be." 
The implementation of management concepts in organizations is typically not a one-time event, but instead should be viewed as a long, drawn-out and complex process. There is a multitude of factors which can influence, for example, whether the concept becomes institutionalized or is quickly discarded (Røvik 2011). In the context of Agile, researchers have noted that the implementation of the concept is a continuous process. Therefore, the implementation of Agile could best be described as a “journey" (Diegmann et al. 2018) or a series of stages (Denning 2018a).

Lastly, an important issue concerning the implementation of Agile is what effects the use of the concept has on organizational performance. While the analysis in Section 4 showed that there is strong rhetoric and lofty promises about the performance-enhancing effects of Agile, the research-based evidence is less clear-cut. There is reason to believe that the high variance in terms of how Agile is interpreted and applied in organizations will lead to differences in terms of the effects of the concept (see e.g., Braam and Nijssen 2004).

\section{Discussion}

\subsection{Emergence}

The historical review has shown that there seems to be some disagreement about the exact origins and birthplace of Agile. However, there appears to be some consensus that the concept is rooted in the software development community (Meyer 2014; Prange and Heracleous 2018b) and that the concept was popularized in the aftermath of the release of the Agile Manifesto (Beck et al. 2001). Therefore, it can be argued that the genealogy of Agile is clearer than for many other management concepts. For example, in the cases of Lean and SWOT Analysis, the genealogies are more complex, and there is considerable disagreement concerning the critical events, inflection points, and influential publications (Holweg 2007; Madsen 2016a).

One interesting aspect of the emergence of Agile is that it has been mostly practice-led. There was little academic involvement in the early phase of the concept's life-cycle. As a result of this, Agile is not a very theoretical concept. However, over time, the concept has been picked up and embraced by academics who have theorized and developed it further, resulting in numerous books and articles on the topic. As noted by Perkmann and Spicer (2008), such work can contribute to turning fashionable management concepts into more permanent organizational practices. The emergence of Agile, therefore, shares some similarities with other concepts (e.g., Benchmarking and Total Quality Management) that have also been spearheaded primarily by actors from the practice domain. For example, in the case of Total Quality Management, academics were passive in the early phase, which gave the quality gurus almost a monopoly over the development of the concept (Wilkinson and Willmott 1996).

\subsection{Evolution}

This section will address several interesting aspects concerning the evolutionary pattern of the Agile concept. With regards to the concept's popularity trajectory, the findings indicate that the supply-side of Agile has played a key role. Over time, the supply-side has become increasingly more active and diverse, as new actors have "hitchhiked on the hype" (cf. Benders et al. 1998) around the Agile concept. Together, the actors supplying Agile have formed what has been called the "Agile Industrial Complex" (Mezick 2016; Wischweh 2019). In the management fashion literature, these actors are referred to as the management fashion arena (e.g., Jung and Kieser 2012; Klincewicz 2006; Madsen and Slåtten 2013). The various sources of evidence reviewed in Section 5 show that there has been-and still is - an active management fashion arena backing and supporting the Agile concept.

Concerning the conceptual evolution of Agile, several interesting observations can be made. The Agile concept is no longer perceived as "exotic" as it was in the beginning (Wischweh 2019). Instead, as shown earlier in this paper, the concept has morphed from a narrow concept (Agile Software Development) to a considerably broader concept (Agile Management), which is presented as being 
applicable in nearly any setting. However, the broadening of the concept has made it harder to define (Prange and Heracleous 2018b; Yip 2016).

The generalization and mainstreaming of Agile bears some similarities with the conceptual evolution of comparable management concepts. For example, Lean started as a specialized concept (Lean Production) focusing mostly on manufacturing but has, over time, become a much broader approach (Benders et al. 2019; Wittrock 2015). One illustrative example is the use of Lean in preschools (Thedvall 2018).

In practice, there are also indications that the Agile concept is increasingly combined with other related management concepts and ideas. There appears to be a process of convergence between Agile and other management concept movements, such as Beyond Budgeting (Bogsnes 2016; Sahota et al. 2014) and Lean (Mason-Jones et al. 2000).

Both Beyond Budgeting and Agile are concepts that share a focus on organizational agility, adaptability, and bottom-up thinking. Moreover, both concepts prescribe moving away from the command-and-control thinking associated with bureaucratic organizations (Bogsnes 2016). Similarly, the concepts of Lean and Agile have been integrated (Medinilla 2012b) into what is sometimes referred to as "Leagile" (Mason-Jones et al. 2000). There have even been attempts to combine all three previously mentioned concepts; i.e., Lean, Agile, and Beyond Budgeting (Sirkiä and Laanti 2015).

From a management fashion perspective, it is interesting to examine the competitive dynamics between these three contemporary management concept movements. After all, all three concepts are competing in the same management knowledge market, offering slightly different prescriptions on management. For the time being, it is unclear what effects the convergence between the Agile, Lean, and Beyond Budgeting concept will have on the respective movements. Will this have a positive impact on all three movements, or will one of them be swallowed by one the others? In previous research, it has been shown that proponents of particular management concepts often try to undermine other management concepts, which occurred in the cases of Benchmarking and Business Process Reengineering, for example (cf. Longbottom 2000).

\subsection{Current Status and Likely Future Trajectory}

Lastly, the paper reflects on the current status of the Agile concept and its likely future trajectory. Taken as a whole, the findings of this study suggest that the Agile concept is "alive and well". Agile is currently dominating public management discourse, both in print and social media. The various sources of evidence reviewed in this paper indicate that Agile fits the definition of a management fashion. Jung and Kieser (2012) point out that management fashions are those "management concepts that relatively speedily gain large shares in the public management discourse" (p. 329).

It is difficult to say anything substantive about the future trajectory of Agile and whether it will stay popular or go out of fashion. While the concept currently has many supporters, there are also critical voices pointing out the weaknesses of the concept. In recent years, there has been considerable debate about the future trajectory and viability of the Agile concept. Despite the current popularity of the concept, there are also potential problems looming on the horizon. There are many critics pointing out the vagueness of the concept and the considerable confusion regarding what the concept really is about. For example, Wischweh (2019) argues that Agile is in a crisis, while Kern (2016) goes as far as to proclaim the death of Agile. In Forbes Magazine, there has recently been a back-and-forth debate about the "end of Agile" (Cagle 2019a, 2019b, 2019c). The last word has probably not been said on this matter.

\section{Conclusions}

\subsection{Contributions}

This paper has shed light on the Agile phenomenon, one of the latest management trends to spread widely in the business community (The Economist 2018). The paper has provided a birds-eye, 
historical view of the concept's emergence and evolution. It is one of few attempts to view Agile through the lens of management fashion theory.

Theoretically, the case of Agile is important to discuss in the context of management fashion theory, as it shows that the Agile movement has yet to slow down. Rather, the concept appears to be picking up speed and attracting new followers across different communities. Moreover, the Agile concept has morphed from a rather narrow and specialized concept to a much broader and general management concept that is impacting a wide range of communities and related discourses. This finding lends further support to the view that management concepts should not be viewed as static entities, but as dynamic and fluid concepts that are translated and may change form as they spread across and within organizations (Benders and Van Veen 2001; Clark 2004; Røvik 2011; Swan 2004).

While it may, at first sight, be difficult to recognize the practical relevance of and direct managerial implications of a detailed case study of the historical emergence and evolution of a popular management concept, it can be argued that taking a critical outside-in view on Agile can be useful for the Agile community as well since it may facilitate self-reflection. The Agile movement tends to be an insular community, which, according to some critics, feels cult-like in its beliefs in the power of Agile (Agile Anon 2016).

Therefore, academic researchers must continue to scrutinize the Agile concept and the views, assumptions, and activities of the members of this community. After all, Agile-inspired thinking is currently influential in many of the largest companies of our time and is seemingly spreading to the public sector as well (Denning 2018b). A better understanding of the phenomenon could enable potential adopters to be more critical consumers of the latest management fashions and organizational trends. This could lead to more realistic implementations, less disappointment and disillusionment, and possibly greater success rates.

\subsection{Limitations and Future Research}

Due to the exploratory nature of the paper, the research has several limitations that should be kept in mind. The research reported in the current paper is based on a desk-research approach. One key limitation related to this type of research is the lack of primary data about the Agile concept. Instead, the paper relies heavily on secondary data, which is a pragmatic choice given the aims and constraints of the study. However, using secondary data to research management concepts has limitations (Nijholt and Benders 2007). Therefore, it is important to stress that the findings of this study only provide a "mosaic picture" of the emergence and evolution of the Agile concept.

The limitations do, however, offer plentiful opportunities for follow-up studies. In this paper, the focus has been on the historical emergence and evolution of Agile at the macro-level. In future studies, researchers could focus on whether being agile is an individual specific characteristic. The literature on unobservable managerial characteristics could be useful here (Coles and Li 2019a, 2019b). Unobservable managerial characteristics include risk aversion, managerial ability/skills, and possibly managerial agility. For example, Graham et al. (2012) find that such characteristics could play a role in determining executive compensation.

In future studies, researchers could gather primary data from actors involved in the marketplace for Agile; e.g., by interviewing experts with a historical overview of key developments and events shaping the Agile field. There is also a wide range of other research methods that could be used to investigate the Agile concept, such as surveys, observations, and textual analyses (Benders et al. 2007; Madsen and Stenheim 2013; Strang and Wittrock 2019).

This paper has taken a mostly big picture and bird's-eye view of the international evolutionary trajectory of Agile. In future studies, researchers could focus on Agile in a particular region, country, or industry. This might allow for comparative analyses and possibly the distillation of factors that could explain similarities and differences.

Another possibility would be to conduct a follow-up study in a few years to examine developments in the popularity of Agile. As noted earlier, the Agile concept is a relatively new phenomenon and one of the relatively few new management concepts introduced since the turn of the millennium. This means 
that many processes are, to a large extent, still unfolding. Future studies could determine whether the positive and optimistic projections of, for instance, Rigby and Bilodeau (2018) will materialize in future years.

Funding: The APC was funded by the University of South-Eastern Norway's Open Access Fund.

Conflicts of Interest: The author declares no conflict of interest.

\section{References}

Abbas, Noura, Andrew M. Gravell, and Gary B. Wills. 2008. Historical Roots of Agile Methods: Where Did "Agile Thinking" Come from? Paper Presented at the International Conference on Agile Processes and Extreme Programming in Software Engineering, Limerick, Ireland, June 10-14; Berlin/Heidelberg: Springer.

Abrahamson, Eric. 1996. Management Fashion. Academy of Management Review 21: 254-85. [CrossRef]

Abrahamson, Eric, and Alessandro Piazza. 2019. The Lifecycle of Management Ideas. In The Oxford Handbook of Management Ideas. Edited by Andrew Sturdy, Stefan Heusinkveld, Trish Reay and David Strang. Oxford: Oxford University Press, pp. 42-67.

Accardi-Petersen, Michelle. 2012. Agile Marketing. New York: Apress.

Aghina, Wouter, Aaron De Smet, and Kirsten Weerda. 2015. Agility: It rhymes with stability. McKinsey Quarterly 51: 2-9.

Agile Alliance. 2020. What is Agile? Available online: https://www.agilealliance.org/agile101/ (accessed on 23 April 2020).

Agile Anon. 2016. 10 Ways Agile Feels Like a Fucking Cult. Available online: https://medium.com/@agileanon/10ways-agile-feels-like-a-fucking-cult-8c1ed74b8882 (accessed on 20 December 2019).

Ahlbäck, Karin, Clemens Fahrbach, Monica Murarka, and Olli Salo. 2017. How to Create an Agile Organization. Available online: https:/www.mckinsey.com/business-functions/organization/our-insights/how-to-createan-agile-organization\# (accessed on 23 April 2020).

Alexandre, J. H. de O., Marcelo L. M. Marinho, and Hermano P. de Moura. 2020. Agile governance theory: Operationalization. Innovations in Systems and Software Engineering 16: 3-44.

Ambler, Scott, and Matthew Holitza. 2012. Agile for Dummies. Hoboken: John Wiley \& Sons.

Anand, Amit, Sahil Merchant, Arun Sunderraj, and Belkis Vasquez-McCall. 2019. Growing Your Own Agility Coaches to Adopt New Ways of Working. Available online: https://www.mckinsey.com/business-functions/ digital-mckinsey/our-insights/growing-your-own-agility-coaches-to-adopt-new-ways-of-working\# (accessed on 23 April 2020).

Augustine, Sanjiv. 2005. Managing Agile Projects. Upper Saddle River: Prentice Hall PTR.

Barros, Marcos, and Charles-Clemens Rüling. 2019. Business Media. In The Oxford Handbook of Management Ideas. Edited by Andrew Sturdy, Stefan Heusinkveld, Trish Reay and David Strang. Oxford: Oxford University Press, pp. 195-215.

Bazigos, Michael, Aaron De Smet, and Chris Gagnon. 2015. Why agility pays. McKinsey Quarterly 4: 28-35.

Beck, Kent, Mike Beedle, Arie Van Bennekum, Alistair Cockburn, Ward Cunningham, Martin Fowler, James Grenning, Jim Highsmith, Andrew Hunt, and Ron Jeffries. 2001. Manifesto for Agile Software Development. Available online: https:/www.semanticscholar.org/paper/Manifesto-for-Agile-SoftwareDevelopment-Beck-Beedle/3edabb96a07765704f9c6a1a5542e39ac2df640c (accessed on 23 April 2020).

Benders, Jos, Robert-Jan van den Berg, and Mark van Bijsterveld. 1998. Hitch-hiking on a hype: Dutch consultants engineering re-engineering. Journal of Organizational Change Management 11: 201-15. [CrossRef]

Benders, Jos. 1999. Tricks and Trucks? A Case Study of Organization Concepts at Work. International Journal of Human Resource Management 10: 624-37. [CrossRef]

Benders, Jos, and Mark Van Bijsterveld. 2000. Leaning on lean: The reception of management fashion in Germany. New Technology, Work and Employment 15: 50-64. [CrossRef]

Benders, Jos, Jurriaan Nijholt, and Stefan Heusinkveld. 2007. Using print media indicators in management fashion research. Quality and Quantity 41: 815-29. [CrossRef]

Benders, J., Marlieke Van Grinsven, and J. Ingvaldsen. 2019. The persistence of management ideas; How framing keeps lean moving. In The Oxford Handbook of Management Ideas. Edited by A. Sturdy, H. Stefan Heusinkveld, Trish Rey and D. Strang. Oxford: Oxford University Press, pp. 271-85. 
Benders, Jos, and Kees Van Veen. 2001. What's in a Fashion? Interpretative Viability and Management Fashions. Organization 8: 33-53. [CrossRef]

Bennett, Nathan, and James Lemoine. 2014a. What VUCA really means for you. Harvard Business Review 92.

Bennett, Nathan, and James Lemoine. 2014b. What a difference a word makes: Understanding threats to performance in a VUCA world. Business Horizons 57: 311-17. [CrossRef]

Bhatta, NMK, and Mohan Thite. 2019. Agile approach to e-HRM project management. e-HRM: Digital Approaches, Directions \& Applications.

Blomstrom, Duena. 2019a. Agile Versus DevOps. Who Cares? Forbes, February 4.

Blomstrom, Duena. 2019b. Agile by Heart Not by McKinsey Power Point. Forbes, February 18.

Blomstrom, Duena. 2019c. Agile-It's Not Business, It's Personal. Forbes.

Blomstrom, Duena. 2019d. Agile Isn't Out, You Are. Forbes, January 16.

Blomstrom, Duena. 2019e. Agile Starts at The Top. Forbes, February 11.

Blomstrom, Duena. 2019f. Leveraging Strong Agile Teams—Are You Being Heard? Forbes, January 22.

Bogsnes, Bjarte. 2016. Beyond Budgeting and Agile. In Implementing Beyond Budgeting. Hoboken: John Wiley \& Sons.

Bort, Suleika. 2015. Turning a management innovation into a management panacea: Management ideas, concepts, fashions, practices and theoretical concepts. In Handbook of Research on Management Ideas and Panaceas: Adaptation and Context. Edited by Anders Örtenblad. Cheltenham: Edward Elgar Publishing Limited, pp. 35-56.

Braam, G., and E. Nijssen. 2004. Performance effects of using the Balanced Scorecard: a note on the Dutch experience. Long Range Planning 37: 335-49. [CrossRef]

Braam, Geert J. M., Jos Benders, and Stefan Heusinkveld. 2007. The balanced scorecard in the Netherlands: An analysis of its evolution using print-media indicators. Journal of Organizational Change Management 20: 866-79. [CrossRef]

Briers, Michael, and Wai Fong Chua. 2001. The role of actor-networks and boundary objects in management accounting change: A field study of an implementation of activity-based costing. Accounting, Organizations and Society 26: 237-69. [CrossRef]

Byker, Martin. 2017. Is Agile a Religion? Available online: https://www.linkedin.com/pulse/agile-religion-martinbyker (accessed on 23 April 2020).

Cagle, Kurt. 2019a. The End of Agile. Forbes, August 23.

Cagle, Kurt. 2019b. The End of Agile: A Rebuttal. Forbes, August 28.

Cagle, Kurt. 2019c. Beyond Agile: The Studio Model. Forbes.

Castellanos, Sara. 2019. Campbell Goes Agile, From Soup to Snacks. Wall Street Journal, July 8.

Choi, Hyunyoung, and Hal Varian. 2012. Predicting the present with google trends. Economic Record 88: 2-9. [CrossRef]

Christensen, Clayton M. 2006. The ongoing process of building a theory of disruption. Journal of Product Innovation Management 23: 39-55. [CrossRef]

Christopher, Martin. 2000. The agile supply chain: Competing in volatile markets. Industrial Marketing Management 29: 37-44. [CrossRef]

Christopher, Martin, Robert Lowson, and Helen Peck. 2004. Creating agile supply chains in the fashion industry. International Journal of Retail \& Distribution Management 32: 367-76.

Clark, Timothy. 2004. The fashion of management fashion: A surge too far? Organization 11: 297-306. [CrossRef] Cluley, Robert. 2013. What Makes a Management Buzzword Buzz? Organization Studies 34: 33-43. [CrossRef]

Coles, Jeffrey L., and Zhichuan Frank Li. 2019a. An Empirical Assessment of Empirical Corporate Finance. Available at SSRN 1787143. Available online: https://papers.ssrn.com/sol3/papers.cfm?abstract_id=1787143 (accessed on 23 April 2020).

Coles, Jeffrey L., and Zhichuan Frank Li. 2019b. Managerial attributes, incentives, and performance. SSRN Working Paper. [CrossRef]

Collabnet Versionone. 2018. 12th State of Agile Report. Atlanta: Collabnet VersionOne, Available online: https://www.stateofagile.com/\#ufh-c-473508-state-of-agile-report (accessed on 15 December 2019).

Collins, David. 2000. Management Fads and Buzzwords. Critical-Practical Perspectives. London: Routledge.

Collins, David. 2019. Management's Gurus. In The Oxford Handbook of Management Ideas. Oxford: Oxford University Press, p. 216. 
Cram, W. Alec, and Sue Newell. 2016. Mindful revolution or mindless trend? Examining agile development as a management fashion. European Journal of Information Systems 25: 154-69. [CrossRef]

David, Robert J., and David Strang. 2006. When fashion is fleeting: Transitory collective beliefs and the dynamics of TQM consulting. Academy of Management Journal 49: 215-33. [CrossRef]

Davies, Nigel. 2019. Agile Deserves the Hype, But It Can Also Fail: How to Avoid the Pitfalls. Forbes, July 2.

Deloitte. 2017. Deloitte Global Human Capital Trends 2017. Rewriting the Rules for the Digital Age. London: Deloitte University Press.

Denning, Stephen. 2012. Is Apple Truly ‘Agile'? Forbes, February 3.

Denning, Stephen. 2015a. Surprise: Microsoft Is Agile. Forbes, October 27.

Denning, Stephen. 2015b. Is Agile Just Another Management Fad? Forbes, June 25.

Denning, Stephen. 2015c. Updating the Agile Manifesto. Strategy E Leadership 43. [CrossRef]

Denning, Stephen. 2015d. How Agile and Zara Are Transforming the US Fashion Industry. Forbes, March 13.

Denning, Stephen. 2015e. How to make the whole organization Agile. Strategy \& Leadership 43: 10-17. [CrossRef]

Denning, Stephen. 2016a. Explaining Agile. Forbes, September 8.

Denning, Stephen. 2016b. Understanding the three laws of Agile. Strategy \& Leadership 44: 3-8. [CrossRef]

Denning, Stephen. 2016c. HBR's embrace of agile. Harvard Business Review 94: 40-50.

Denning, Stephen. 2017a. The age of Agile. Strategy E Leadership 45: 3-10. [CrossRef]

Denning, Stephen. 2017b. The next frontier for Agile: Strategic management. Strategy E Leadership 45: 12-18.

Denning, Stephen 2018a. The 12 Stages of the Agile Transformation Journey. Forbes, November 4.

Denning, Stephen. 2018b. What The C-Suite Must Do to Make the Whole Firm Agile. Forbes, September 9.

Denning, Stephen. 2018c. Why Agile Is Eating the World. Forbes, January 2.

Denning, Stephen. 2018d. Ten Agile axioms that make conventional managers anxious. Strategy E Leadership 46: 10-16. [CrossRef]

Denning, Stephen. 2018e. The role of the C-suite in Agile transformation: The case of Amazon. Strategy E Leadership 46: 14-21. [CrossRef]

Denning, Stephen. 2018f. Ten Agile Axioms That Make Managers Anxious. Forbes, June 17.

Denning, Stephen. 2018g. The emergence of Agile people management. Strategy E Leadership 46: 3-10.

Denning, Stephen. 2018h. How major corporations are making sense of Agile. Strategy E Leadership 46: 3-9. [CrossRef]

Denning, Stephen. 2018i. Why Finding the Real Meaning of Agile Is Hard. Forbes, September 16.

Denning, Stephen. 2018j. The Age of Agile: How Smart Companies Are Transforming the Way Work Gets Done. New York: Amacom.

Denning, Stephen. 2018k. Agile Is Not Just Another Management Fad. Forbes, July 30.

Denning, Steve. 20181. Succeeding in an increasingly Agile world. Strategy E Leadership 46: 3-9. [CrossRef]

Denning, Stephen. 2019a. World Agility Forum Celebrates Excellence, Flays Fake Agile. Forbes, October 13.

Denning, Stephen. 2019b. HR Reinvents the Organization. Forbes, October 4.

Denning, Stephen. 2019c. The Five Biggest Challenges Facing Agile. Forbes, September 8.

Denning, Stephen. 2019d. How Mapping the Agile Transformation Journey Points the Way to Continuous Innovation. Forbes, March 17.

Denning, Stephen. 2019e. Post-bureaucratic management goes global. Strategy E Leadership 47: 19-24.

Denning, Stephen. 2019f. The ten stages of the Agile transformation journey. Strategy E Leadership 47: 3-10.

Denning, Stephen. 2019g. The Irresistible Rise of Agile: A Paradigm Shift in Management. Forbes, February 20.

Denning, Stephen. 2019h. Lessons learned from mapping successful and unsuccessful Agile transformation journeys. Strategy \& Leadership 47: 3-11.

Denning, Stephen. 2019i. Recognizing Excellence in Agility: The World Agility Forum. Forbes, September 1.

Diegmann, Phil, Tim Dreesen, BjÃrn Binzer, and Christoph Rosenkranz. 2018. Journey Towards Agility: Three Decades of Research on Agile Information Systems Development. Paper Presented at the International Conference on Information Systems, San Francisco, CA, USA, December 13-16.

Dierdorf, Scott. 2019. Becoming Agile. Tiffany Taylor 410.

Dingsøyr, Torgeir, Sridhar Nerur, VenuGopal Balijepally, and Nils Brede Moe. 2012. A Decade of Agile Methodologies: Towards Explaining Agile Software Development. Amsterdam: Elsevier.

Doz, Yves, and Mikko Kosonen. 2008. The dynamics of strategic agility: Nokia's rollercoaster experience. California Management Review 50: 95-118. [CrossRef] 
Doz, Yves L., and Mikko Kosonen. 2010. Embedding strategic agility: A leadership agenda for accelerating business model renewal. Long Range Planning 43: 370-82. [CrossRef]

Dybå, Tore, and Torgeir Dingsøyr. 2008. Empirical studies of agile software development: A systematic review. Information and Software Technology 50: 833-59. [CrossRef]

Engwall, Lars, and Linda Wedlin. 2019. Business Studies and Management Ideas. In Oxford Handbook of Management Ideas. Edited by Andrew Sturdy, Stefan Heusinkveld, Trish Reay and David Strang. Oxford: Oxford University Press.

Felizardo, Katia Romero, Emilia Mendes, Marcos Kalinowski, Érica Ferreira Souza, and Nandamudi L Vijaykumar. 2016. Using forward snowballing to update systematic reviews in software engineering. Paper Presented at the 10th ACM/IEEE International Symposium on Empirical Software Engineering and Measurement, Ciudad Real, Spain, September 8-9.

Forbes Insights. 2018. Management in the Age of Agile. Forbes, November 8.

George, Joey F., Kevin Scheibe, Anthony M. Townsend, and Brian Mennecke. 2018. The amorphous nature of agile: No one size fits all. Journal of Systems and Information Technology. [CrossRef]

Graham, John R., Si Li, and Jiaping Qiu. 2012. Managerial attributes and executive compensation. The Review of Financial Studies 25: 144-86. [CrossRef]

Gren, Lucas, and Per Lenberg. 2019. Agility is responsiveness to change: An essential definition. arXiv arXiv:1909.10082.

Grint, Keith. 1997. TQM, BPR, JIT, BSCs and TLAs: Managerial waves or drownings? Management Decision 35: 731-38. [CrossRef]

Gunasekaran, Angappa. 1998. Agile manufacturing: Enablers and an implementation framework. International Journal of Production Research 36: 1223-47. [CrossRef]

Gunasekaran, Angappa. 2001. Agile Manufacturing: The 21st Century Competitive Strategy. Amsterdam: Elsevier. Hass, Kathleen B. 2007. The blending of traditional and agile project management. PM World Today 9: 1-8.

Hazzan, Orit, and Yael Dubinsky. 2014. Agile Anywhere: Essays on Agile Projects and Beyond. Berlin: Springer.

Heiligtag, S., D. Luczak, and E. Windhagen. 2015. Agility lessons from utilities. McKinsey Quarterly.

Heusinkveld, S., and J. Benders. 2012. Consultants and organization concepts. In The Oxford Handbook of Management Consulting. Edited by M. Kipping and T. Clark. New York: Oxford University Press, pp. 267-84.

Heusinkveld, Stefan. 2013. The Management Idea Factory: Innovation and Commodification in Management Consulting. New York: Routledge.

Hindle, Tim. 2008. Guide to Management Ideas and Gurus. London: The Economist in Assocation with Profile Books Ltd.

Hoda, Rashina, Norsaremah Salleh, and John Grundy. 2018. The rise and evolution of agile software development. IEEE Software 35: 58-63. [CrossRef]

Holweg, Matthias. 2007. The genealogy of lean production. Journal of Operations Management 25: 420-37. [CrossRef] Horney, Nick, Bill Pasmore, and Tom O'Shea. 2010. Leadership agility: A business imperative for a VUCA world. Human Resource Planning 33: 34.

Hosking, Alan. 2018. Agile leaders balance speed and stability. HR Future 2018: 10-11.

Huczynski, Andrzej. 1993. Management Gurus: What Makes Them and How to Become One. London: Routledge.

Huczynski, Andrzej A. 1992. Management Guru Ideas and the 12 Secrets of their Success. Leadership E Organization Development Journal 13: 15-20. [CrossRef]

Hussain, Mostaque, and A. Gunasekaran. 2002. Non-financial management accounting measures in Finnish financial institutions. European Business Review 14: 210-29. [CrossRef]

Jalali, Samireh, and Claes Wohlin. 2012. Systematic literature studies: Database searches vs. backward snowballing. Paper Presented at the 2012 ACM-IEEE International Symposium on Empirical Software Engineering and Measurement, Lund, Sweden, September 20-21.

Johnson, Mark W. 2010. Seizing the White Space: Business Model Innovation for Growth and Renewal. Brighton: Harvard Business Press.

Jung, Dong-II, and Won-Hee Lee. 2016. Crossing the management fashion border: The adoption of business process reengineering services by management consultants offering total quality management services in the United States, 1992-2004. Journal of Management \& Organization, 1-18. [CrossRef]

Jung, Nicole, and Alfred Kieser. 2012. Consultants in the Management Fashion Arena. In The Oxford Handbook of Management Consulting. Edited by Matthias Kipping and Timothy Clark. New York: Oxford University Press, pp. 327-46. 
Kaarbøe, Katarina, Paul N. Gooderham, and Hanne Nørreklit. 2013. Managing in Dynamic Business Environments: Between Control and Autonomy. Trotterham: Edward Elgar Publishing.

Kern, M. 2016. Agile Is Dead. Available online: http://www.linkedin.com/pulse/agile-dead-matthew-kern (accessed on 20 December 2019).

Kieser, Alfred. 1997. Rhetoric and myth in management fashion. Organization 4: 49-74. [CrossRef]

Kieser, Alfred. 2002. Managers as Marionettes? Using Fashion Theories to Explain the Success of Consultancies. In Management Consulting_Emergence and Dynamics of a Knowledge Industry. Edited by Matthias Kipping and Lars Engwall. Oxford: Oxford University Press.

Kim, W. Chan, and Renée Mauborgne. 2005. Blue Ocean Strategy: How to Create Uncontested Market Space and Make the Competition Irrelevant. Boston: Harvard Business School Press.

Kim, W. Chan, and Renée Mauborgne. 2017. Blue Ocean Shift: Beyond Competing_Proven Steps to Inspire Confidence and Seize New Growth. New York: Hachette Books.

Klincewicz, Krzysztof. 2006. Management Fashions: Turning Best-Selling Ideas into Objects and Institutions. Praxiology: The International Annual of Practical Philosophy and Methodology. Piscataway: Transaction Publishers, vol. 13.

Kotter, John P. 2014. Accelerate: Building Strategic Agility for a Faster-Moving World. Harvard: Harvard Business Review Press.

Kruchten, Philippe. 2019. The end of agile as we know it. In Proceedings of the International Conference on Software and System Processes. Montreal: IEEE Press.

Kupersmith, Kupe. 2011. Agile Is a Fad. July 4. Available online: http://www.batimes.com/kupe-kupersmith/ agile-is-afad.html (accessed on 23 April 2020).

Laanti, Maarit, Rami Sirkiä, and Mirette Kangas. 2015. Agile portfolio management at Finnish broadcasting company Yle. Scientific Workshop Proceedings of the XP2015. [CrossRef]

Layton, Mark C., and Steven J. Ostermiller. 2017. Agile Project Management for Dummies. Hoboken: John Wiley \& Sons.

Lewis, Marianne W., Constantine Andriopoulos, and Wendy K. Smith. 2014. Paradoxical leadership to enable strategic agility. California Management Review 56: 58-77. [CrossRef]

Longbottom, David. 2000. Benchmarking in the UK: An empirical study of practitioners and academics. Benchmarking: An International Journal 7: 98-117. [CrossRef]

Macias-Lizaso, Gloria, and Kiko Thiel. 2006. Building a nimble organization: A McKinsey global survey. The McKinsey Quarterly-Online Survey, 1-7.

Madsen, Dag, and Kåre Slåtten. 2013. The Role of the Management Fashion Arena in the Cross-National Diffusion of Management Concepts: The Case of the Balanced Scorecard in the Scandinavian Countries. Administrative Sciences 3: 110-42. [CrossRef]

Madsen, Dag Øivind, and Tonny Stenheim. 2013. Doing research on 'management fashions': Methodological challenges and opportunities. Problems and Perspectives in Management 11: 68-76.

Madsen, Dag Øivind. 2014. How do managers encounter fashionable management concepts? A study of balanced scorecard adopters in Scandinavia. International Journal of Management Concepts and Philosophy 8: 249-267. [CrossRef]

Madsen, Dag Øivind, and Kåre Slåtten. 2015a. The Balanced Scorecard: Fashion or Virus? Administrative Sciences 5: 90-124. [CrossRef]

Madsen, Dag Øivind, and Kåre Slåtten. 2015b. Social media and management fashions. Cogent Business $\mathcal{E}$ Management 2: 1122256. [CrossRef]

Madsen, Dag Øivind. 2016a. SWOT Analysis: A Management Fashion Perspective. International Journal of Business Research 16: 39-56. [CrossRef]

Madsen, Dag Øivind. 2016b. Using Google Trends in management fashion research: A short note. European Journal of Management 16: 111-22. [CrossRef]

Mason-Jones, Rachel, Ben Naylor, and Denis R. Towill. 2000. Engineering the leagile supply chain. International Journal of Agile Management Systems 2: 54-61. [CrossRef]

Medinilla, Ángel. 2012a. Agile Management: Leadership in an Agile Environment. Berlin/Heidelberg: Springer Science \& Business Media.

Medinilla, Ángel. 2012b. Lean and Agile in a Nutshell. In Agile Management: Leadership in an Agile Environment. Berlin/Heidelberg: Springer, pp. 19-52.

Mergel, Ines. 2016. Agile innovation management in government: A research agenda. Government Information Quarterly 33: 516-23. [CrossRef] 
Mergel, Ines, Yiwei Gong, and John Bertot. 2018. Agile Government: Systematic Literature Review and Future Research. Amsterdam: Elsevier.

Meyer, Bertrand. 2014. Agile!: The Good, the Hype and the Ugly. Berlin/Heidelberg: Springer Science \& Business Media. Meyer, Pamela. 2016. Agility Shift: Creating Agile and Effective Leaders, Teams, and Organizations. New York: Routledge. Mezick, Daniel. 2016. The Agile Industrial Complex. Available online: http://newtechusa.net/aic/ (accessed on 23 April 2020).

Millar, Carla CJM, Olaf Groth, and John F. Mahon. 2018. Management Innovation in a VUCA World: Challenges and Recommendations. California Management Review 61: 5-14. [CrossRef]

Moore, Jed. 2017. An ethnography of multiplicity: Wittgenstein and plurality in the organisation. Paper Presented at the 12th Annual International Ethnography Symposium, Manchester, UK, August 29-September 1.

Morrison, Alan, and Robin Wensley. 1991. Boxing up or boxed in?: A short history of the Boston Consulting Group share/growth matrix. Journal of Marketing Management 7: 105-29. [CrossRef]

Nicoletti, Bernardo. 2018. Introduction to Agile Procurement Systems. In Agile Procurement: Volume II: Designing and Implementing a Digital Transformation. Cham: Springer International Publishing, pp. 1-4.

Nijholt, J. J., and J. Benders. 2007. Coevolution in management fashions. Group E Organization Management 32: 628-52.

Nyce, Caroline Mimbs. 2017. The Winter Getaway That Turned the Software World Upside Down: How a group of programming rebels started a global movement. The Atlantic, December 8.

Perkmann, Markus, and André Spicer. 2008. How are Management Fashions Institutionalized? The Role of Institutional Work. Human Relations 61: 811-44. [CrossRef]

Piazza, Alessandro, and Eric Abrahamson. 2020. Fads and Fashions in Management Practices: Taking Stock and Looking Forward. International Journal of Management Reviews. [CrossRef]

Poolton, Jenny, Hossam S. Ismail, Iain R. Reid, and Ivan C. Arokiam. 2006. Agile marketing for the manufacturing-based SME. Marketing Intelligence \& Planning 24: 681-93.

Prange, Christiane, and Loizos Heracleous. 2018a. Agility.X: How Organizations Thrive in Unpredictable Times. Cambridge: Cambridge University Press.

Prange, Christiane, and Loizos Heracleous. 2018b. Introduction. In Agility.X: How Organizations Thrive in Unpredictable Times. Edited by Christiane Prange and Loizos Heracleous. Cambridge: Cambridge University Press, pp. 1-16.

Rigby, Darrell, Jeff Sutherland, and Hirotaka Takeuchi. 2016a. The Secret History of Agile Innovation. Harvard Business Review, April 20.

Rigby, Darrell, Jeff Sutherland, and Hirotaka Takeuchi. 2016b. Embracing Agile. Harvard Business Review, May.

Rigby, Darrell, and Barbara Bilodeau. 2018. Management Tools E Trends.

Rigby, Darrell K., Steve Berez, Greg Caimi, and Andrew Noble. 2015. Agile Innovation. San Francisco: Bain \& Company.

Røvik, Kjell Arne. 1998. Moderne Organisasjoner. Oslo: Fagbokforlaget.

Røvik, Kjell Arne. 2002. The secrets of the winners: Management ideas that flow. In The Expansion of Management Knowledge: Carriers, Ideas and Sources. Edited by K. Sahlin-Andersson and L. Engwall. Stanford: Stanford University Press, pp. 113-44.

Røvik, Kjell Arne. 2011. From Fashion to Virus: An Alternative Theory of Organizations' Handling of Management Ideas. Organization Studies 32: 631-53. [CrossRef]

Sahlin-Andersson, Kerstin, and Lars Engwall. 2002. Carriers, Flows, and Sources of Management Knowledge. In The Expansion of Management Knowledge. Edited by Kerstin Sahlin-Andersson and Lars Engwall. Stanford: Stanford Business Books-Stanford University Press, pp. 3-32.

Sahota, Michael, Bjarte Bogsnes, Jaana Nyfjord, Jorgen Hesselberg, and Almir Drugovic. 2014. Beyond Budgeting: A Proven Governance System Compatible with Agile Culture. Available online: http://bbrt.co.uk/bbfiles/ BeyondBudgetingAgileWhitePaper_2014.pdf (accessed on 23 April 2020).

Schwarz, Colleen. 2015. A review of management history from 2010-2014 utilizing a thematic analysis approach. Journal of Management History 21: 494-504. [CrossRef]

Scully, Jim. 2013. Agile HR delivery. Workforce Solutions Review 4: 8-12.

Shellenbarger, Sue. 2019. Are You Agile Enough for Agile Management. Wall Street Journal, August 12.

Sibbet, David. 1997. 75 years of management ideas and practice 1922-1997. Harvard Business Review 75: 2-12.

Sirkiä, Rami, and Maarit Laanti. 2013. Lean and agile financial planning. White Paper 24: 2013. 
Sirkiä, Rami, and Maarit Laanti. 2015. Adaptive Finance and Control: Combining Lean, Agile, and Beyond Budgeting for Financial and Organizational Flexibility. Paper Presented at the 201548 th Hawaii International Conference on System Sciences (HICSS), Kauai, HI, USA, January 5-8.

Skeels, Jack. 2018. Will Management Succeed at Killing Agile? And can true leadership save it? June 24.

Soe, Ralf-Martin, and Wolfgang Drechsler. 2018. Agile local governments: Experimentation before implementation. Government Information Quarterly 35: 323-35. [CrossRef]

Stormi, Kati Tuulikki, Teemu Laine, and Tuomas Korhonen. 2019. Agile performance measurement system development: An answer to the need for adaptability? Journal of Accounting $\mathcal{E}$ Organizational Change 15: 231-56.

Strang, David, and Christian Wittrock. 2019. Methods for the Study of Management Ideas. In Oxford Handbook of Management Ideas. Edited by Andrew Sturdy, Stefan Heusinkveld, Trish Reay and D. Strang. Oxford: Oxford University Press, pp. 86-103.

Sturdy, Andrew. 2004. The adoption of management ideas and practices. Theoretical perspectives and possibilities. Management Learning 35: 155-79. [CrossRef]

Sturdy, Andrew, Stefan Heusinkveld, Trish Reay, and David Strang. 2019. The Oxford Handbook of Management Ideas. Oxford: Oxford University Press.

Sull, Donald. 2010. Competing through organizational agility. McKinsey Quarterly 1.

Swan, Jacky. 2004. Reply to Clark: The fashion of management fashion. Organization 11: 307-14. [CrossRef]

Sørhaug, Tian. 2016. Gull, Arbeid og Galskap: Penger og Objekttrøbbel. Fagbokforlaget Vigmostad og Bjørke. Bergen: Fagbokforlaget Vigmostad og Bjørke.

Taipaleenmäki, Jani. 2017. Towards Agile Management Accounting: A Research Note on Accounting Agility. In A Dean, a Scholar, a Friend: Texts in Appreciation of Markus Granlund. Edited by Kari Lukka. Turku: University of Turku, pp. 175-204.

Taleb, Nassim Nicholas. 2007. The Black Swan: The Impact of the Highly Improbable. New York: Random House. ten Bos, René. 2000. Fashion and Utopia in Management Thinking. Amsterdam/Philadelphia: John Benjamins.

The Economist. 2018. The fashion for agile management is spreading. Cirrus, July 5.

Thedvall, Renita. 2018. Plans for Altering Work: Fitting Kids into Car-Management Documents in a Swedish Preschool. Anthropologica 60: 236-45. [CrossRef]

Tuckman, Alan. 1994. The yellow brick road: Total quality management and the restructuring of organizational culture. Organization Studies 15: 727-51. [CrossRef]

Twidale, Michael, and Preben Hansen. 2019. Agile research. First Monday, 24.

Ulrich, Dave, and Arthur Yeung. 2019. Agility: The new response to dynamic change. Strategic HR Review 18: 161-67. [CrossRef]

Versionone. 2017. 11st State of Agile Report. Atlanta: Versionone, Available online: https://www.stateofagile.com/ \#ufh-i-338501295-11th-annual-state-of-agile-report/473508 (accessed on 20 December 2019).

Weiderstål, Robin, and Isak Nilsson Johansson. 2018. Translating Agile: An Ethnographic Study of SEB Pension \& Försäkring. Available online: http://www.diva-portal.org/smash/record.jsf?pid=diva2\%3A1221071\&dswid= -9003 (accessed on 23 April 2020).

Whiteley, Andrew, Julien Pollack, and Petr Matous. 2019. A Structured Review of the History of Agile Methods and Iterative Approaches to Management. Academy of Management Proceedings. [CrossRef]

Wilkinson, Adrian, and Hugh Willmott. 1995. Making Quality Critical: New Perspectives on Organizational Change. New York: Routledge.

Wilkinson, Adrian, and Hugh Willmott. 1996. Quality management, problems and pitfalls: A critical perspective. International Journal of Quality E Reliability Management 13: 55-65.

Wischweh, Jan. 2019. The Agile Crisis-A Primer. Available online: https://blog.usejournal.com/the-agile-crisis2016-9fb1c2f52af5 (accessed on 23 April 2020).

Wittrock, Christian. 2015. Reembedding Lean: The Japanese Cultural and Religious Context of a World Changing Management Concept. International Journal of Sociology 45: 95-111. [CrossRef]

Wohlin, Claes. 2014. Guidelines for snowballing in systematic literature studies and a replication in software engineering. Paper Presented at the 18th International Conference on Evaluation and Assessment in Software Engineering, London, UK, May 13-14.

Yip, Jason. 2016. What do you mean when you say "Agile"? June 19. 
Yusuf, Yahaya Y., Mansoor Sarhadi, and Angappa Gunasekaran. 1999. Agile manufacturing: The drivers, concepts and attributes. International Journal of Production Economics 62: 33-43. [CrossRef]

Örtenblad, Anders. 2010. Who needs contingency approaches and guidelines in order to adapt vague management ideas? International Journal of Learning and Change 4: 64-76. [CrossRef]

(C) 2020 by the author. Licensee MDPI, Basel, Switzerland. This article is an open access article distributed under the terms and conditions of the Creative Commons Attribution (CC BY) license (http://creativecommons.org/licenses/by/4.0/). 